\title{
Health Belief Model Theory Application on Voluntary Counseling and Testing among Homosexual Men in Bandung Greater Area
}

\author{
Argya Nareswara, ${ }^{1}$ Chrysanti Murad, ${ }^{2}$ Irvan Afriandi ${ }^{3}$ \\ ${ }^{1}$ Faculty of Medicine Universitas Padjadjaran, ${ }^{2}$ Department of Microbiology Faculty of Medicine \\ Universitas Padjadjaran, ${ }^{3}$ Department of Public Health Faculty of Medicine Universitas \\ Padjadjaran
}

\begin{abstract}
Background: The number of human immunodeficiency virus (HIV) cases is high and is constantly increasing. Homosexual men as a transmission niche is not only significant in terms of numbers, but also in natural aspects of anal sex, tropism of HIV-1, and high-risk behavior. Voluntary Counseling and Testing (VCT) is important for accelerating diagnosis and management plan; yet the uptake on high-risk population in Indonesia is low. A behavior-reasoning theory, Health Belief Model (HBM), attempts to explain whether or not individuals engage in certain health behavior. This study tries to assess participation rate of VCT, to portray HBM variables perception, and to depict significance of HBM variables towards VCT uptake or VCT intention.

Methods: This study was conducted in October-November 2014 using cross-sectional design; 127 respondents were gathered according to Respondent Driven Snowball Sampling. This study used an internet-based questionnaire derived from Champion's 1984 mammogram HBM questionnaire. Privacy and compensation were obtained. The Chi square test and logistic regression of HBM variables were done.

Results: The VCT uptake was low (15.7\%). Certain sexual experience and commitment were significant (Commitment to Men $\mathrm{p}=0.027$, Oral Sex experience with men $\mathrm{p}=0.001$, Anal Sex Experience with men $\mathrm{p}=0.038$ ). Chi Square test revealed significance on Perceived Susceptibility, Perceived Benefit, and Cues to Action.

Conclusions: Uptake of VCT is considerably low compared with total high risk population and other similar studies. Personal Susceptibility to HIV/AIDS is recommended to be emphasized; while VCT Benefit and Cues to Action in young homosexual men communities are better encouraged. [AMJ.2016;3(4):595-604]
\end{abstract}

Keywords: Health Belief Model, HIV, Homosexual, VCT

\section{Introduction}

Since 2014, infection of human immunodeficiency virus (HIV) has been a global problem that has not been solved. With 30.000 .000 positive individuals globally and 2.500.000 global case incidence per year, the number of HIV-positive individual is increasing day by day. ${ }^{1}$ In Indonesia, the prevalence of HIV Infection has reached $0.2 \%$ among general population. In addition, cumulative HIV cases reported until June 2012 reached 86.762 cases, whereas cumulative Acquired Immunodeficiency Syndrome (AIDS) cases reported from 1987 until June 2012 was 32.103 cases. $^{2,3}$

Homosexual men are considered more susceptible to be infected by HIV because of HIV-1 tropism in large intestine endothelial cells, low condom usage, and high promiscuity which make the odds of being infected by HIV 18.7 times higher compared with those in heteronormative adult population in Asia. ${ }^{1,4-8}$ With the lowest estimation of $2.2 \%$ proportion from the total male population, men who have sex with men (MSM) is HIV-transmitting niche that is quite big. ${ }^{9}$ In Indonesia, for instance, HIV/AIDS is positive in around $2.1 \%$ MSM in Bandung, 5.6\% in Surabaya, and $8.1 \%$ in Jakarta. ${ }^{10}$

Voluntary counseling and testing (VCT) is a serial of rapid test, education, and counseling regarding HIV/AIDS intended to helping individuals to know their HIV status, to understand the behavior they might

Correspondence: Argya Nareswara, Faculty of Medicine, Universitas Padjadjaran, Jalan Raya Bandung-Sumedang Km.21, Jatinangor, Sumedang, Indonesia, Phone: +6289656067175 Email: rgynrswr@gmail.com 
have to adopt in the future, and to motivate them in defending seronegative status; or at least avoiding the progression of diseases for seropositive individuals. Regardless of psychological benefit and acceleration of management plan, VCT has not covered up to $70 \%$ of high-risk population, including straight-acting MSM, transgender, and sex worker. ${ }^{11}$ MSM health seeking behavior percentage also only reaches $42.6 \%$; regardless HIV/AIDS knowledge among Indonesian MSM categorized as quite good..$^{10}$

Based on Health Belief Model (HBM), the tendency for an individual to do certain health behavior is a result from six perceptions conflicting inside the individual's mind. Those perceptions are: 1) Perceived Severity, how individuals see certain disease could give irresistible harm; 2) Perceived Susceptibility, how individuals see themselves being prone to acquire the disease; 3) Perceived Benefit, how individuals see benefit from adopting the behavior; 4) Perceived Barrier, how individuals oversee particular reasons to not doing so or foreseen harms that may exist from adapting the behavior ; 5) Cues to Action, how certain events stimulate individuals' motivation; and 6) Self Efficacy, on how individuals must have a belief that they will be able to adopt a behavior before they try to. This study attempts to reveal VCT uptake on homosexual individuals in Bandung; their intention in undergoing VCT on individual who have not undertaken VCT. In addition, it is also intended to picture the Health Belief Model variables as well as the association between the HBM variables over the intention in undertaking the VCT.

\section{Methods}

This study was an analytic study with crosssectional approach. It was carried out from October to November 2014 by using internetbased questionnaire. Ethical Clearance had been reviewed by Health Research Ethics Committee of Universitas Padjadjaran, issued on 6 October 2014 (No. 0114070642). Permission had been secured from all participating respondents. Confidentiality was maintained during and after the study.

This study was performed in Bandung Greater Area (Kota Bandung, Kota Cimahi, Kabupaten Bandung, Kabupaten Bandung Barat, Kabupaten Sumedang). Bandung Greater Area was chosen due to 1) easy access towards VCT services, 2) availability of HIV epidemiology data, particularly on MSM population, 3) logistical advantages for researcher, 4) availability of good internet for conducting online-based questionnaire filling.

Sample size was determined by the rule of thumb analysis; how it was estimated by the amount of variables. It was considered that 20 respondents were enough to represent one variable, and it was estimated that required sample size was 120 . Sampling size under regression logistic procedure was also conducted yet it was assumptive, since there was no data concerning the proportion of homosexual population in Indonesia.

The sampling procedure used was Respondent-Driven Snowball Sampling targeted on self-declared 'men who love men' rather than "homosexual men". It was done in order to prevent possible technical conflicts due to unclear limitations between homosexuals and bisexuals. RDS was used due to wide-spread stigma against homosexuality in Indonesia. The sampling procedure used several seeds (respondent contributing other respondent with $1 \$$ incentive per respondent given) to increase the trust between respondents and researcher. Gay finder mobile applications, such as Grindr and Jack'd, were also used.

Personal information and Health Belief Model perception were collected by onlinebased form to maintain the privacy of respondents. Questionnaire was composed in Bahasa, and was derived from Champion's questionnaire for mammograms. The questionnaire had been validated with statistic processor (Cronbach Alpha for Perceived Seriousness: 0.731; Perceived Susceptibility: 0.739; Perceived Benefit 0.759; Perceived Barrier 0,804, Cues to Action 0.795; and Self Efficacy 0.700). The questionnaire consisted of 32 questions (6 questions for each perception, with the exception of 4 questions for Perceived Susceptibility and Self Efficacy). Perceptions under Health Belief Model were illustrated by Likert's Scale; ranging from strongly agree to strongly disagree; and were classified into two groups; 1 ) good, if the score passed the means from well-distributed data, or the median from not well-distributed data, and 2) bad, if perception score was below the means or the median.

Completeness of inspections was done by investigator before statistical analysis. Chisquare test was used in order to portray the association between HBM perceptions and socio-demographic characteristics (education background and occupation, abstinence status, history of relationship, and engagement of sexual activity) against respondents' 
Argya Nareswara, Chrysanti Murad, Irvan Afriandi: Health Belief Model Theory Application on Voluntary 597 Counseling and Testing among Homosexual Men in Bandung Greater Area

Table 1 Characteristics of VCT uptake stratified by Abstinence Status

\begin{tabular}{|c|c|c|c|c|}
\hline \multirow[b]{2}{*}{ Abstinence Status } & \multicolumn{2}{|c|}{ No VCT Uptake (\%) } & \multirow[b]{2}{*}{$\begin{array}{c}\text { Positive VCT Uptake } \\
\text { (\%) }\end{array}$} & \multirow[b]{2}{*}{ Total (\%) } \\
\hline & $\begin{array}{l}\text { No intention for } \\
\text { VCT uptake }\end{array}$ & $\begin{array}{c}\text { Positive } \\
\text { intention for } \\
\text { VCT uptake }\end{array}$ & & \\
\hline $\begin{array}{l}\text { Have been engaged in } \\
\text { same sex activity. }\end{array}$ & $19(15 \%)$ & $54(42.5 \%)$ & $18(14.2 \%)$ & $91(71.7 \%)$ \\
\hline \multicolumn{5}{|l|}{$\begin{array}{l}\text { Have not been engaged } \\
\text { in same sex activity; }\end{array}$} \\
\hline $\begin{array}{l}\text { and planned to do so } \\
\text { in the future. }\end{array}$ & $2(1.6 \%)$ & $5(3.9 \%)$ & 0 & $7(5.5 \%)$ \\
\hline $\begin{array}{l}\text { and planned not to do } \\
\text { so in the future. }\end{array}$ & $3(2.4 \%)$ & $2(1.6 \%)$ & 0 & $5(3.9 \%)$ \\
\hline $\begin{array}{l}\text { and have been } \\
\text { thinking about doing it } \\
\text { in the future. }\end{array}$ & $6(4.7 \%)$ & $3(2.4 \%)$ & 0 & $9(7.1 \%)$ \\
\hline $\begin{array}{l}\text { and have never been } \\
\text { thinking about doing it } \\
\text { in the future. }\end{array}$ & $9(7.1 \%)$ & $4(3.1 \%)$ & $2(1.6 \%)$ & $15(11.8 \%)$ \\
\hline Total & $39(30.7 \%)$ & $68(53.5 \%)$ & 20 (15.7\%) & $127(100 \%)$ \\
\hline
\end{tabular}

willingness to undertake the VCT. Logistic regression later was used to determine the most influential factor.

\section{Results}

Initial respondents had amounted to 143 individuals, however eventually only 127 $(88.8 \%)$ of the respondents completed the online questionnaires. Thirteen respondents were excluded from the study, 4 respondents were below 18 years old, 2 respondents had different gender construct (transgender), and 7 respondents filled in the questionnaire from 2 or more different seeds]. There were 27 first degree respondents, 19 second degree respondents, and 81 third degree respondents.

Among them, 99 (77.9\%) respondents were university student, and 15 of these were studying in health-related faculty. Private employee amounted to 14 respondents $(11 \%)$, while artist and self-employed respondents amounted to 3 respondents (2.3\%). The rests consisted of the small portion of governments' worker, university lecturer, prostitute, and engineer. The total population means age was $21.13+2.254$ years. Most of the respondents, 87 respondents $(68.5 \%)$, had finished their general high school, while 5 respondents (3.9\%) had finished their vocational high school degree. Only $1(0.8 \%)$ respondent had the background of junior high school, while 20 respondents (15.7\%) had finished their bachelor degree and 8 people (6.3\%) had finished their diploma degree. The rest 6 respondents $(4.7 \%)$ had finished their postgraduate education.

Ninety one respondents $(71.7 \%)$ had engaged in same-sex sexual activity, with oral sex as the most common activity (85 persons or $66.9 \%$ ) . Anal sex was experienced by 58 $(45.7 \%)$ respondents. The history of same-sex commitment was lower compared with oral sex engagement, with only 80 respondents (63.0\%) engaging into it.

Heteronormative relationship and sexual engagement were observed in the small proportion of respondent. Heteronormative commitment was reported by 62 respondents $(48.8 \%)$, while oral sex with women was experienced by 15 respondents $(11.8 \%)$, and genital sex or anal sex was reported by 9 respondents $(9.1 \%)$.

Uptake of VCT was positive only on 20 respondents (15.7\%), while 120 (84.3\%) respondents had not undertaken the VCT serial. The VCT uptake was commonly higher in sexually active group of homosexuals, with $90 \%$ (18 out of 20 ) respondents who had undertaken the VCT originating from this group.

The intention for undertaking VCT was taken from the population who had not undertaken the VCT. Sixty eight (53.5\%) out of 107 respondents who had not undertaken 
Table 2 Distribution of Perceived Severity and Perceived Susceptibility in the total population

\begin{tabular}{|c|c|c|c|c|c|}
\hline Statements & $\begin{array}{c}\text { Strongly } \\
\text { Agree }\end{array}$ & Agree & Do not Know & Disagree & $\begin{array}{l}\text { Strongly } \\
\text { Disagree }\end{array}$ \\
\hline \multicolumn{6}{|l|}{ Perceived Severity } \\
\hline Fear of discussing HIV/AIDS & $19(15)$ & $37(29.1)$ & $47(37.0)$ & $15(11.8)$ & $9(7.1)$ \\
\hline $\begin{array}{l}\text { Pain experienced when } \\
\text { acquired with HIV/AIDS }\end{array}$ & $36(28.3)$ & $65(51.2)$ & $12(9.4)$ & $11(8.7)$ & $3(2.4)$ \\
\hline $\begin{array}{l}\text { Damage on Relationship with } \\
\text { partner }\end{array}$ & $42(33.1)$ & $54(42.5)$ & $18(14.2)$ & $11(8.7)$ & $2(1.6)$ \\
\hline Damage on Career & $47(37)$ & $45(35.4)$ & $11(8.7)$ & $18(14.2)$ & $6(4.7)$ \\
\hline Hard to be Cured & $44(34.6)$ & $61(48.0)$ & $9(7.1)$ & $12(9.4)$ & $1(0.8)$ \\
\hline $\begin{array}{l}\text { Assumption that information } \\
\text { regarding HIV/AIDS are very } \\
\text { important }\end{array}$ & $59(46.5)$ & $41(32.3)$ & $8(6.3)$ & $14(11.0)$ & $5(3.9)$ \\
\hline \multicolumn{6}{|l|}{ Perceived Susceptibility } \\
\hline $\begin{array}{l}\text { Assumption of Susceptibility } \\
\text { due to Sexual Orientation }\end{array}$ & $17(13.4)$ & $53(41.7)$ & $29(22.8)$ & $18(14.2)$ & $10(7.9)$ \\
\hline $\begin{array}{l}\text { Fear of Unconsciously taking } \\
\text { high-risk behavior }\end{array}$ & $30(23.6)$ & $68(53.5)$ & $21(16.5)$ & $6(4.7)$ & $2(1.6)$ \\
\hline Inability to Control Behavior & $5(39)$ & $26(20.5)$ & $39(30.7)$ & $46(36.2)$ & $11(8.7)$ \\
\hline $\begin{array}{l}\text { Assumption of HIV/AIDS } \\
\text { infection inclusivity }\end{array}$ & $7(5.5)$ & $34(26.8)$ & 47 (37.) & $32(25.2)$ & $7(5.5)$ \\
\hline
\end{tabular}

VCT had the intention to undertake the VCT. Positive intention for VCT uptake was noted in every group; $74.0 \%$ (54 out of 73 ) on sexually active group, $71.4 \%$ (5 out of 7 ) on group who planned to engage sexual activity in the future, $40 \%$ ( 2 out of 5 ) on group who planned not to engage in sexual activity in the future, $33 \%$ (3 out of 9) on group who had been thinking about engaging in sexual activity in the future, and $26 \%$ (4 out of 15) from group who had not been thinking about engaging in sexual activity.

Over seventy percent of the respondents believed that HIV/AIDS would inflict irresistible pain, harmed onto relationship with partner, and harmed onto their career. The idea of HIV/AIDS that is hard to be cured was also perceived well on above seventy percent respondents. Perceived Susceptibility scores were not well distributed (KolmogorovSmirnov value $=0.021$ ). The median for perceived severity for total respondent was 23 and 24 for the respondents who had not committed to do the VCT. The means was 23.23 +3.971 for the total population and $23.64+$ 3.689 for those who had not committed to do the VCT. There were 41 respondents with high level of perception and 66 respondents with low level of perception.

The assumption on susceptibility due to sexual orientation, perception of inability to control behavior, and fear of getting infected unconsciously were observed on over half of the respondents. Perceived Susceptibility scores were not well distributed (KolmogorovSmirnov value $=0.001$ ). Median for perceived susceptibility for total respondent was 13 for both groups; while the means was 13.08 +2.311 for the total population and $13.04+$ 2.343 for those who had not committed to do the VCT. There were 49 respondents with high level of perception, and 58 respondents with low level of perception.

Personal emotional benefit and relieve, trust from partner, and sexual health awareness were also discovered in majority $(70 \%)$ of the respondents as personal benefit of undertaking the VCT. Perceived Benefit scores were well-distributed (KolmogorovSmirnov value $=0.106$ ). The means for perceived benefit for the total respondent was $23.15+3.326$ and $23.00+3.232$ for the respondents who had not committed to do the VCT. Additionally, the median was 23.00 for the total population and 23.00 for the respondents who had not committed to do the 
Argya Nareswara, Chrysanti Murad, Irvan Afriandi: Health Belief Model Theory Application on Voluntary 599 Counseling and Testing among Homosexual Men in Bandung Greater Area

Table 3 Distribution of Perceived Benefit and Perceived Barrier in total population.

\begin{tabular}{|c|c|c|c|c|c|}
\hline Statements & $\begin{array}{l}\text { Strongly } \\
\text { Agree }\end{array}$ & Agree & Donot Know & Disagree & $\begin{array}{l}\text { Strongly } \\
\text { Disagree }\end{array}$ \\
\hline \multicolumn{6}{|l|}{ Perceived Benefit } \\
\hline $\begin{array}{l}\text { Relieved feeling when } \\
\text { knowing HIV status }\end{array}$ & $29(22.8)$ & $69(48.8)$ & $23(18.1)$ & $10(7.9)$ & $3(2.4)$ \\
\hline $\begin{array}{l}\text { Personal benefit from } \\
\text { knowing HIV status }\end{array}$ & $26(20.5)$ & $70(55.1)$ & $24(18.9)$ & $7(5.5)$ & 0 \\
\hline Peer support on VCT uptake & $18(14.2)$ & $53(41.7)$ & $47(37.0)$ & $8(6.3)$ & $1(0.8)$ \\
\hline Partner's trust & $30(23.6)$ & $62(48.8)$ & $28(22.0)$ & $6(4.7)$ & $1(0.8)$ \\
\hline $\begin{array}{l}\text { Emotional state (stability, no } \\
\text { guilt) difference from knowing } \\
\text { HIV status }\end{array}$ & 15 (11.8) & $76(59.8)$ & $36(28.3)$ & 0 & 0 \\
\hline $\begin{array}{l}\text { Reproductive health } \\
\text { awareness }\end{array}$ & $30(23.6)$ & $78(61.4)$ & $17(13.4)$ & $2(1.6)$ & 0 \\
\hline \multicolumn{6}{|l|}{ Perceived Barrier } \\
\hline $\begin{array}{l}\text { No shame for starting VCT } \\
\text { uptake }\end{array}$ & $4(19.7)$ & $25(19.7)$ & 38 (29.9) & $44(34.6)$ & $16(12.6)$ \\
\hline No financial insecurity & $10(7.9)$ & $26(20.5)$ & $50(39.4)$ & $37(29.1)$ & $4(3.1)$ \\
\hline $\begin{array}{l}\text { No fear of gossip come from } \\
\text { others if somebody knew } \\
\text { about VCT history }\end{array}$ & $3(2.4)$ & $22(17.3)$ & $36(28.3)$ & $50(39.4)$ & $16(12.6)$ \\
\hline No laziness for VCT uptake & $4(3.1)$ & $24(18.9)$ & $47(37.0)$ & $44(34.6)$ & $8(6.3)$ \\
\hline $\begin{array}{l}\text { Belief on counselor integrity } \\
\text { that would not gossiping } \\
\text { about }\end{array}$ & $10(7.9)$ & $20(15.7)$ & $36(28.3)$ & $48(37.8)$ & $13(10.2)$ \\
\hline No assumption of time-waste & $2(1.6)$ & $11(8.7)$ & $44(34.6)$ & $57(44.9)$ & $13(10.2)$ \\
\hline
\end{tabular}

VCT. Over half of the respondents $(n=61)$ was categorized as having high perception; while the rest, 46 respondents were categorized as having low perception.

Barriers to undertaking the VCT were commonly observed. Feeling of shame and laziness were observed in over $40 \%$ of the respondents. Additionally, feeling offeargetting mocked by others and fear of being gossiped by health care provider were observed in over half of the respondents. Perceived Barrier scores were not well distributed (KolmogorovSmirnov value $=0.033$ ). The median for perceived barrier of the total respondents and for the respondents who had not committed to do the VCT was 17; while the means was 17.29 +4.053 for the total population and $16.96+$ 3.843 for those who had not committed to do the VCT. The scores of Perceived Barrier had been converted into positive measurement as other variables for easiness in handling data. There were 45 respondents with high perception of perceived barrier (having little or no barrier) and 62 respondents with low perception of perceived barrier (having a lot of barrier).

Partner's HIV status and partner request were more appreciated (both observed in over $60 \%$ of the respondents) as a cue to action compared with family HIV status, family support, and public figure with HIV status (observed only around 50\%, 30\%, and 20\% within each of the respondent). Cues to Action scores were not well distributed (KolmogorovSmirnov value $=0.007$ ). The median for perceived severity for the total respondent and for the respondent who had not committed to do the VCT was 21; while the means was 20.59 +3.878 for the total population and $20.89+$ 3.596 for those who had not committed to do the VCT. There are 48 respondents with low level of perception and 59 respondents with high level of perception.

Trust to health care provider professionalism and self-trust to finish the whole VCT series were commonly observed in around $50 \%$ of the respondents. On the contrary, self-trust in deciding to undertake 
Table 4 Distribution of Cues to Action and Self Efficacy in total population

\begin{tabular}{|c|c|c|c|c|c|}
\hline Statements & $\begin{array}{c}\text { Strongly } \\
\text { Agree }\end{array}$ & Agree & Do not Know & Disagree & $\begin{array}{l}\text { Strongly } \\
\text { Disagree }\end{array}$ \\
\hline \multicolumn{6}{|l|}{ Cues To Action } \\
\hline Motivated by family request & $10(7.9)$ & $36(28.3)$ & $40(31.5)$ & $35(27.6)$ & $6(4.7)$ \\
\hline Motivated by partner request & $17(13.4)$ & $56(44.1)$ & $29(22.8)$ & $18(14.2)$ & $7(5.5)$ \\
\hline $\begin{array}{l}\text { Motivated by family with HIV } \\
\text { status }\end{array}$ & $17(13.4)$ & $54(42.5)$ & $36(28.3)$ & $15(11.8)$ & $5(3.9)$ \\
\hline $\begin{array}{l}\text { Motivated by Partner with HIV } \\
\text { status }\end{array}$ & $50(39.4)$ & $57(44.9)$ & $11(8.7)$ & $6(4.7)$ & $3(2.4)$ \\
\hline $\begin{array}{l}\text { Motivated by sudden increase } \\
\text { of HIV cases }\end{array}$ & $24(18.9)$ & $56(44.1)$ & $32(25.2)$ & $9(7.1)$ & $6(4.7)$ \\
\hline $\begin{array}{l}\text { Motivated by public figure's/ } \\
\text { role model's HIV status }\end{array}$ & $4(3.1)$ & 25 (19.7) & $51(40.2)$ & $32(25.2)$ & $15(11.8)$ \\
\hline \multicolumn{6}{|l|}{ Self-Efficacy } \\
\hline Bravery to uptake VCT & $22(17.3)$ & $33(26.0)$ & $51(40.2)$ & $14(11.0)$ & $7(5.5)$ \\
\hline Trust on other actors on VCT & $13(10.2)$ & $62(48.8)$ & $43(33.9)$ & $7(5.5)$ & $2(1.6)$ \\
\hline $\begin{array}{l}\text { Trust that VCT doesn't } \\
\text { intimidate self-past }\end{array}$ & $6(4.7)$ & 39 (30.7) & $54(42.5)$ & $23(18.1)$ & $5(3.9)$ \\
\hline $\begin{array}{l}\text { Self-trust to commit and to be } \\
\text { able to finish VCT until the end. }\end{array}$ & $13(10.2)$ & $58(45.7)$ & $46(36.2)$ & $10(7.9)$ & 0 \\
\hline
\end{tabular}

the VCT or not was only observed in around $40 \%$ of the respondents. Self-Efficacy mean scores were not well distributed (KolmogorovSmirnov value $=0.000$ ). The median for perceived severity on the total respondents and the respondents who had not committed to do the VCT was 14; while the means was $13.72+2.031$ for the total population and 13.82 +1.994 for those who had not committed to do the VCT. There were 70 respondents with low level of self-efficacy and 37 respondents with high level of self- efficacy.

Significance of the VCT intention was shown from several socio-demographic status and sexual activity engagement. Age only showed its significance on the age of 19 when it was compared with the age of 18 as the reference value, without any significance on further older age. Education background and occupation did not show any significance. Significances were revealed on history of same-sex relationship $[\mathrm{OR}=2.924,95 \%$ CI $(1.278,6.688) ; \mathrm{p}=0.010]$, history of oral sex with same-sex partner [OR=4.206, 95\% CI (1.806, 9.794); $p=0.001]$, and history of anal sex with same-sex partner [OR=2.391, 95\% CI $(1.038,5.504) ; p=0.038]$. No significance was observed from any heteronormative commitment or sexual activity.

Chi-square analysis also portrayed the significance of Cues to Action when adjusted with the VCT intention [OR=2.531, 95\% CI $(1.104,5.806) ; p$ value $=0.026]$. Significance was also shown by Perceived Susceptibility and Perceived Benefit, with [OR=3.224, 95\% CI $(1.384,7.531) ; p$ value $=0.006]$ and [OR $3.345,95 \%$ CI $(1.472,7.605)$; $p$ value $=0.003$ ] respectively. Perceived barrier, Self-Efficacy, and Perceived Severity did not depict significant statistic association with the intention to undertake the VCT. Only Perceived Susceptibility showed significance when tested using logistic regression $[\operatorname{Exp}(B)=3.223$, CI 95\% (1.350, 7.691); $p=0.008)]$.

\section{Discussion}

The use of online-based questionnaire was preferred due to recommendation issued by Health Ethic Research Committee of Universitas Padjadjaran. In addition, the preference was also because several crime cases done in homosexual community weeks before ethical clearance had been issued. Nevertheless, the use of online-based questionnaire had been implemented to hidden and privacy-needing community, such as what had been done in Madrid, Spain. ${ }^{12}$

The uptake of VCT in this study population 
Table 5 Willingness for Having VCT among homosexuals who have not undertaken $\neg$ VCT versus socio-demographic variables, Bandung, $2014(n=107)$

\begin{tabular}{|c|c|c|c|}
\hline \multirow{2}{*}{ Variable } & \multicolumn{2}{|c|}{ Willingness to VCT } & \multirow{2}{*}{ Crude OR 95\% CI } \\
\hline & Yes & No & \\
\hline \multicolumn{4}{|l|}{ Age } \\
\hline $18^{* *}$ & 4 & 5 & 1.00 \\
\hline 19 & 13 & 2 & $8.125(1.115,59.212)^{*}$ \\
\hline 20 & 16 & 15 & $1.333(0.300,5.926)$ \\
\hline 21 & 19 & 6 & $3.958(0.796,19.674)$ \\
\hline 22 & 11 & 3 & $4.583(0.733,28.646)$ \\
\hline Over 22 & 5 & 8 & $0.781(0.139,4.387)$ \\
\hline \multicolumn{4}{|l|}{ Educational Status } \\
\hline $\begin{array}{l}\text { Have not Finished Tertiary } \\
\text { Education } * *\end{array}$ & 54 & 27 & 1.00 \\
\hline $\begin{array}{l}\text { Have Finished Tertiary } \\
\text { Education }\end{array}$ & 14 & 12 & $0.583(0.247,1.433)$ \\
\hline \multicolumn{4}{|l|}{ History of Partnership with Men } \\
\hline No** & 18 & 20 & 1.00 \\
\hline Yes & 50 & 19 & $2.924(1.278,6.688)^{*}$ \\
\hline \multicolumn{4}{|l|}{ History of Oral Sex with Men } \\
\hline $\mathrm{No}^{* *}$ & 16 & 22 & 1.00 \\
\hline Yes & 52 & 17 & $4.206(1.806,9.794)^{*}$ \\
\hline \multicolumn{4}{|l|}{ History of Anal Sex with Men } \\
\hline $\mathrm{No}^{* *}$ & 32 & 27 & 1.00 \\
\hline Yes & 34 & 12 & $2.391(1.038,5.504)^{*}$ \\
\hline \multicolumn{4}{|l|}{ History of Partnership with Women } \\
\hline No** & 30 & 19 & 1.00 \\
\hline Yes & 38 & 20 & $1.203(0.546,2.650)$ \\
\hline \multicolumn{4}{|l|}{ History of Oral Sex with Women } \\
\hline $\mathrm{No}^{* *}$ & 60 & 33 & 1.00 \\
\hline Yes & 8 & 6 & $0.733(0.234,2.294)$ \\
\hline \multicolumn{4}{|l|}{$\begin{array}{l}\text { History of Genital/Anal Sex with } \\
\text { Women }\end{array}$} \\
\hline $\mathrm{No}^{* *}$ & 62 & 36 & 1.00 \\
\hline Yes & 6 & 3 & $1.161(0.274,4.928)$ \\
\hline
\end{tabular}

was low, compared with UNAIDS statement. That coverage was still lacking, coveredonly up to $30 \%$ of the total high risk population. ${ }^{11}$ However, this number was taken from all participants, regardless their sexual experience. If VCT uptake was analyzed only from the population who had experienced sex, which we shifted the population from homosexual onto MSMs, the proportion would be $19.78 \%$. Yet even if it was higher, it was still lower compared with the study conducted by van Griensvenet al. ${ }^{10}$ in Indonesia stating that the VCT coverage towards MSM reached 31.9\%. In the other hand, it is considered higher if we compared with the study conducted by Pisaniet et al. ${ }^{4}$ in Jakarta, stating that less 
Table 6 Willingness for Having VCT among Homosexuals who Have not Undertaken the VCT versus HBM Variables, Bandung, $2014(n=107)$

\begin{tabular}{|c|c|c|c|c|}
\hline \multirow{2}{*}{ Variable } & \multicolumn{2}{|c|}{ Willingness to VCT } & \multirow{2}{*}{ Crude OR 95\% CI } & \multirow{2}{*}{ Adjusted OR 95\% CI } \\
\hline & Yes & No & & \\
\hline \multicolumn{5}{|l|}{ Perceived Severity } \\
\hline Low $^{* *}$ & 40 & 26 & 1.00 & 1.00 \\
\hline High & 28 & 13 & $1.400(0.615,3.187)$ & $1.146(0.441,2.978)$ \\
\hline \multicolumn{5}{|c|}{ Perceived Susceptibility } \\
\hline Low $^{* *}$ & 30 & 28 & 1.00 & 1.00 \\
\hline High & 38 & 11 & $3.224(1.384,7.513)^{*}$ & $2.786(1.112,6.975)^{*}$ \\
\hline \multicolumn{5}{|l|}{ Perceived Benefit } \\
\hline Low $^{* *}$ & 22 & 24 & 1.00 & 1.00 \\
\hline High & 46 & 15 & $3.345(1.472,7.605)^{*}$ & $2.322(0.927,5.817)$ \\
\hline \multicolumn{5}{|l|}{ Perceived Barrier } \\
\hline Low $^{* *}$ & 37 & 25 & 1.00 & 1.00 \\
\hline High & 31 & 14 & $1.496(0.666,3.363)$ & $1.719(0.679,4.353)$ \\
\hline \multicolumn{5}{|l|}{ Cues To Action } \\
\hline $\operatorname{Low}^{* *}$ & 32 & 27 & 1.00 & 1.00 \\
\hline High & 36 & 12 & $2.531(1.104,5.806)^{*}$ & $2.196(0.862,5.546)$ \\
\hline \multicolumn{5}{|l|}{ Self-Efficacy } \\
\hline Low ${ }^{* *}$ & 41 & 29 & 1.00 & 1.00 \\
\hline High & 27 & 10 & $1.910(0.802,4.547)$ & $1.185(0.445,3.158)$ \\
\hline
\end{tabular}

Note: ${ }^{*}=$ significance with $\mathrm{p}$ value $<=0.05^{* *}=$ reference category

than 3\% of any MSM group had undertaken VCT regardless their exposure onto health promotion campaign. However, $15.8 \%$ of the total homosexual population - or even $19.78 \%$ for high risk MSM - was considerably very low if we compared with the National Strategy 2010-2014, since it was targeted to cover $56.0 \%$ high risk MSM in 2013. ${ }^{13}$ It was also lower compared with the study conducted by Chariyalertsaket al. ${ }^{8}$ in Northern Thailand, where VCT uptake reached 55.9\% coverage on the total MSM communities. Compared with other study that targeted heteronormative men, this number is still lower; for example, compared with the study conducted by Kabiru et al. ${ }^{14}$ in Kenya (19\%), and the study conducted by Bwambale et al. ${ }^{15}$ in Uganda $(23.3 \%)$. Studies about Health Belief Model variables against VCT, which extensively conducted in Africa and other developing countries, rarely touched homosexual men; while the study about homosexual reproductive health that extensively conducted in developed countries with low stigma regarding homosexuality rarely analyzed the decision- making psychology and frequently ended on descriptive statistic about health-seeking behavior. This study gave deeper analysis on it, thus allowed us to see HBM variables on these vulnerable group.

Perceived Severity was observed insignificant, different from the study conducted by Abebe et al. ${ }^{16}$ targeting high school students in Ethiopia. Yet on the other hand, Perceived Severity characteristics were remarkably good. Perceived Barrier also revealed significant results on the study conducted by Abebe et al. ${ }^{16}$, which possibly caused by difference stigma and epidemiology of HIV between Sub-Saharan Africa and South East Asia; with the addition of different characteristic from homosexual and heteronormative samples.

Perceived Susceptibility was observed significantly positive, in contrast with the study conducted by Abebeet al. ${ }^{16}$ which discovered significantly negative. In the other hand, Perceived Susceptibility is also positively significant on the study conducted by Moges et al. ${ }^{17}$ regarding the VCT uptake on pregnant 
women. Qualitative study is needed to portray high risk population's Perceived Susceptibility, other factors that probably interfere Perceived Susceptibility, and psychological defense mechanisms of being susceptible.

Perceived Benefit was discovered significantly positive, in line with the study conducted by Abebe et al. ${ }^{16}$ on high school students and the study conducted by Mogeset al. ${ }^{17}$ on pregnant women. Perceived Barrier in this study was different compared with other study, which in this study, perceived barrier was a score of the total perception regarding all barrier. In other study, every single barrier was tested against intention of VCT uptake thus made this variable incomparable.

Cues to Action in this study is also incomparable with other study extensively done in Africa with different HIV-AIDS epidemiology. This might give different perception of getting infected or died by HIV. Deeper studies that could differentiate HIV perception on region with higher and lower death rate might be needed to reveal whether cues to action from these different regions could be comparable.

Self-Efficacy was observed insignificance, in contrast with the study conducted by Berendes et al. ${ }^{18}$ on heterosexual community in Malawi. Not only that, Berendes et al. ${ }^{18}$ even proved that Self-Efficacy was significant on population who had previous VCT uptake. In the other hand, study conducted by Berendes et al. ${ }^{18}$ in Malawi was exclusively discussing Self-Efficacy as independent variables, not as a part of HBM variables. This difference might be caused by more number of question Berendes et al. $^{18}$ offered, and wider range of HIV/AIDS preventive measurements involved (VCT was included). Similar difference was found on the study conducted by Andrinapulous et al. in Jamaica. ${ }^{19}$ In the end, the difference of Self-Efficacy on homosexual population and heteronormative population needed to be analyzed deeper.

The limitation of this study concerns about age variability among respondents. This study revealed high number of data regarding young age homosexuals; and mostly university students homosexual. It was considered as normal consequences of Respondent Driven Snowball Sampling, and most of the seeds contributing in this study were university students. It strengthened the results of this towards the needs of young homosexuals who were discovered active sexually to undertake VCT as emerging subgroup of homosexual as high risk population. Even so, this study might not represent the whole homosexual community. For instance, long term relationship which is possibly common on older homosexual, could strengthen Cues to Action due to more intense compassion coming from partner. On the other hand, it also might lessen compromise on high risk behavior due to trust onto partner. Additionally, it might lessen compromise on high risk behavior such as in heteronormative marriage, and might interfere with Perceived Susceptibility. The problem is not only coming from HBM variables, but also from the HIV epidemiology point of view. Newly diagnosed homosexuals was increased on men older than 34 years old but not in younger men was revealed in Amsterdam. ${ }^{20}$ Engagement of this new trend was not achieved in this study, and might become the cause of insignificancy of age group, occupation, and educational background.

This study also needs improvements to be implemented in the future. Higher sampling seeds variability is recommended. History of using condoms, number of previous sex partner, swallowing sperm from partner, and other non-sexual HIV high risk behavior such as intravenous drugs, piercing, and tattoo history need to be noted down to strengthen the study History of first sexual experience also needs to be analyzed and might explain anomaly on age significance on this study.

From the above mentioned explanation, it can be concluded that VCT uptake was low on homosexual community in Bandung, with uptake rates of $15.74 \%$. Intentions to undertake VCT were observed on 68 respondents, or $63.55 \%$ among those who had not undertaken VCT. There were high engagement on same-sex sexual activities and even engagement of same sex sexual activities were higher compared to engagement onto same-sex relationship. Perceived Susceptibility is significance on both Chi Square and Logistic Regression test, while Perceived Benefit and Cues to Action were significance on Chi Square test. Based on our findings, Perceived Susceptibility strengthening in advocating VCT coverage was recommended, so were with personal benefit encouragement, and opportunity taking in every cue.

\section{References}

1. Beyrer C, Baral SD, Griensven Fv, Goodreau SM, Chariyalertsak S, Wirtz AL, et al.. Global epidemiology of HIV infection in men who have sex with men. Lancet. 
2012;380(9839):367-77.

2. Irvan Afriandi, Tjandra Yoga Aditama, Dyah Mustikawati, Martiani Oktavia, Bachti Alisjahbana, Pandji Riono. HIV and injecting drug use in Indonesia: epidemiology and national response. Acta Med Indones. 2009;41(Suppl1):75-8.

3. Tri Paryati, Ardini S. Raksanegara, Irvan Afriandi. Factors Influencing Stigmatization and Discrimination of PLHA (People living with HIV/AIDS) among health workers : literature review. Pustaka Unpad [Online Journal] 2012. [cited 2014 April 3] Available online from: http:// pustaka.unpad.ac.id/archives/124593

4. Pisani E, Girault P, Gultom M, Sukartini N, Kumalawati J, Jazan ED. HIV, syphilis infection, and sexual practices among transgenders, male sex workers, and other men who have sex with men in Jakarta, Indonesia. Sex Transm Infect. 2004;80:536-40.

5. Berg RC, Tikkanen R, Ross MW. Barebacking among men who have sex with men recruited through a Swedish website: associations with sexual activities at lastsexual encounter. Euro Surveill. 2013;18(13):pii=24308.

6. Perez-Brumer AG, Konda KA, Salvatierra HJ, Segura ER, Hall ER, Montano SM, et al.. Prevalence of HIV, STIs, and risk behaviors in a cross- sectional community- and clinic-based sample of men who have sex with men (MSM) in Lima, Peru. PloS One. 2013;8(4):1-5.

7. Jung M, Lee J, Kwon DS, Park BJ. Comparison of sexual risky factors of men who have sex with men and sex-buying men as groups vulnerable to sexually transmitted diseases. J Prev Med Public Health. 2012;45(3):156-63.

8. Chariyalertsak S, Kosachunhanan N, Saokhieo P, Songsupa R, Wongthanee A, Chariyalertsak C, et al.. HIV incidence, risk factors, and motivation for biomedical intervention among gay, bisexual men, and transgender persons in Northern Thailand. PloS One. 2011;6(9):1-8.

9. Chandra A, Mosher WD, Copen C, Sionean C. Sexual behavior, sexual attraction, and sexual identity in the United States: data from the 2006-2008 National Survey of Family Growth. Natl Health Stat Report. 2011;36:1-36.

10. Van Griensven F, de Lind van Wijngaarden JW. A review of the epidemiology of HIV infection and prevention responses among MSM in Asia. AIDS. 2010;24(Suppl3):S30-40.

11. Elmira N Sumintardja, Pinxten LW, Juke RL Siregar, Harry Suherman, Rudi Wisaksana, Shelly Iskandar, et al.. Behavioral aspects of HIV prevention and care in Indonesia: a plea for a multi-disciplinary, theoryand evidence-based approach. Acta Med Indones. 2009;41(Suppl1):79-86.

12. Fernández-Dávila P, Lorca KZ. Young men who have sex with men: a group at high risk for HIV infection?.Gaceta Sanitaria. 2011;25(5):372-8.

13. Tromp N, Siregar A, Leuwol B, Komarudin D, Ven Avd, Crevel Rv, et al.. Costeffectiveness of scaling up voluntary counselling and testing. Acta Med Indones. 2013;45(1):17-25.

14. Kabiru CW, Beguy D, Crichton J, Zulu EM. HIV/AIDS among youth in urban informal (slum) settlements in Kenya: what are the correlates of and motivations for HIV testing?. BMC Public Health. 2011;11(685):1471-58.

15. Bwambale FM, Ssali SN, Byaruhanga S, Kalyango JN, Karamagi CA. Voluntary HIV counselling and testing among men in rural western Uganda: implications for HIV prevention. BMC Public Health. 2008;8(263).

16. Abebe A, Mitikie G. Perception of high school students towards voluntary HIV counseling and testing, using health belief model in Butajira, SNNPR. Ethiop J Health Dev. 2009;23(2):148-53.

17. Moges Z, Amberbir A. Factors associated with readiness to VCT service utilization among pregnant women attending antenatal clinics in northwestern ethiopia: a health belief model approach. Ethiop J Health Sci. 2011;21(Suppl 1):107-15.

18. Berendes S, Rimal RN. Addressing the slow uptake of HIV testing in Malawi: the role of stigma, self-efficacy, and knowledge in the Malawi BRIDGE Project. J Assoc Nurses AIDS Care. 2011;22(3):215-28

19. Andrinopoulos K, Kerrigan D, Figueroa JP, Reese R, Ellen JM. HIV coping self efficacy: a key to understanding stigma and HIV test acceptance among incarcerated men in Jamaica. AIDS Care. 2010;22(3):339-47.

20. Hamers FF, Downs AM. The changing face of the HIV epidemic in western Europe: what are the implications for public health policies?. Lancet. 2004;364(9428):83-94. 